\title{
Civil recovery and international issues in relation to restraint and confiscation
}

This article and the one that follows - "Civil interventions for tackling MTIC fraud: a UK perspective", by Steven Pope and Roderick Stone - were taken from presentations given at a half day seminar held at the Institute of Advanced Legal Studies on November 12, 2009. The seminar, "Civil recoveries and criminal confiscation: UK and EU interventions against fraud," was chaired by Dr Simone White of the European Anti-Fraud Office (OLAF), Visiting Fellow at the IALS.

by Philip F J Mobedji

\section{INTRODUCTION}

The Serious Crime Act 2007 states: "A relevant authority must exercise its functions under this Act in the way which it considers is best calculated to contribute to the reduction of crime.” It further states: “...the reduction of crime is best secured by means of criminal investigations and criminal proceedings" (See Sched 8, Pt 6 under heading "Contribution to Reduction of Crime").

In my opinion civil recovery work is not, nor should it be, a substitute for criminal investigations, prosecutions and criminal confiscation. Civil recovery ought to be undertaken in circumstances where criminal confiscation is not possible.

It may be helpful to summarise briefly the way in which civil recovery claims are brought. The claimant agency (Serious Fraud Office (SFO); Crown Prosecution Service (CPS) and Serious Organised Crime Agency (SOCA)) has to establish to the civil standard of proof that property has been obtained by unlawful conduct (ie the commission of crime here or abroad) and that the property, or other property which can be shown through the tracing provisions in the Act to "represent" it, is held by the respondent. The proceedings may involve a "property freezing order" being made to prevent disposal of assets in question pending the resolution of the case. The claims are begun in the Administrative Court under the Civil Procedure Rules Part 8 procedure.

The procedural stages involved are:

(a) the claimant agency will issue a claim form and make an application supported by a witness statement setting out the evidence to establish the claim; (b) the respondent to file an acknowledgement of service and a witness statement setting out his claim;

(c) the court holds a case management conference to decide what future steps (if any) are required before the hearing of the case;

(d) the hearing of the Part 8 claim takes place unless the matter is disposed of by summary judgment under Part 24 or settlement.

In practice the procedure may be more complicated. For example, it may be necessary for the agency to ask for the appointment of a receiver to manage the property in issue and conduct an investigation leading to a report to the court as to whether the property identified and any other property held by the respondent is "recoverable." The respondent may apply for the release of frozen funds to take appropriate steps to secure his interests and may object to the Part 8 procedure and ask for the case to proceed under Part 7 (ie with a timetable for detailed pleadings, extensive disclosure and service of witness statements leading up to full trial).

To avoid delay it is suggested that the claimant agency should take a more pro-active part in the case management process and that, in almost every case, at an early stage insist that the respondent submits a witness statement setting out in some detail the nature of his answer to the claim that the property in question is or represents property obtained by unlawful conduct.

\section{WHEN SHOULD A PROSECUTING AUTHORITY CONDUCT CIVIL RECOVERY?}

In my view civil recovery would be appropriate in cases in the following circumstances: 
(a) It is decided that there is not to be a prosecution, either for lack of evidence or on public interest grounds, and civil recovery requirements are met.

(b) A prosecution fails and civil recovery requirements are met.

(c) Where defendant absconds (before or after conviction) or dies.

(d) Civil recovery may be a primary means of recovery where a corporate entity has changed beyond all recognition from its predecessor.

The above criteria are not to be treated as conclusive and each case will need to be considered on its special facts and merits. What should not happen, I believe, is to use civil recovery as a substitute for criminal confiscation where the latter is possible, especially where there are victims to compensate from the alleged offending (see also the Attorney General's Guidelines on civil recovery).

It is worth mentioning here that:

(i) Cases should not be taken on by a prosecuting authority only for civil recovery purposes. In other words, the prosecuting authority should not become a substitute Asset Recovery Agency.

(ii) There are serious risks of costs and damages if civil recovery fails, unlike in most criminal confiscation cases. There is, however, a temptation to go down the civil recovery route, especially given the ruling in the cases of $R_{v}$ David Gale [2009] EWHC 1015 (QB) (currently on appeal to the Supreme Court) and $R_{v}$ Briggs-Price [2009] 2 WLR 1101 (HL).

(iii) In Gale, SOCA alleged that all the property was the proceeds of drug trafficking (largely taking place in Spain \& Portugal in the 1980s and 90s) associated laundering or tax evasion. There was no conviction for drug trafficking - in fact the defendant had been tried in Portugal and acquitted. The court found that this was proved on a balance of probabilities and ordered forfeiture. The case is on appeal.

(iv) In Briggs-Price there has been both an expansion and contraction of the scope of confiscation orders. It gives the green light for confiscation for offences for which there has been no conviction and the use of evidence for an extremely wide purpose, but at the same time introduces a contraction because such matters have to be proved beyond reasonable grounds - the criminal standard, and that is a threshold which few confiscation proceedings will be able to meet.

(v) It also important to ensure that civil recovery is not pursued because it is the easier option and that there are not double standards where large and rich corporations by self-reporting unlawful activity "buy their way" out of criminal proceedings. There will be cases where, prima facie, civil recovery seems appropriate, but if the offence is serious then justice demands that there is adequate punishment for the offence beyond depriving the offender of ill-gotten gain.

\section{CIVIL RECOVERY AND MUTUAL LEGAL ASSISTANCE TO FOREIGN JURISDICTIONS}

If assets within the English jurisdiction are obtained by unlawful conduct in a foreign state then these can be forfeited provided there is sufficient evidence from that foreign jurisdiction that the assets located here were obtained by unlawful conduct in that foreign state even without a conviction in the foreign state. It is strictly therefore not mutual legal assistance to a foreign state as in criminal cases of mutual legal assistance. Civil recovery will only be pursued if evidence is provided by the foreign state that the assets were obtained by unlawful conduct.

\section{COMPENSATION TO VICTIMS}

This area is not without its difficulties. Compensation is envisaged in the criminal regime. Under the civil recovery route there is no mechanism to compensate victims of crime. The only available option would be under section 281 Proceeds of Crime Act 2002 (POCA) where the "victim" would need to make a declaration acceptable to the court that he/she has an interest in recoverable property or property subject to civil recovery. It is the "victim" who has to make the necessary claim. The agency pursuing civil recovery cannot do so. Section 283 of POCA may be an answer to this particular difficulty read in conjunction with sections 281 and 286 of POCA. The authority conducting civil recovery may, if satisfied, ask for a declaration of a victim's interest in recoverable property. If it is the policy to compensate victims of fraud, particularly those who, unlike large organisations, are without the financial resources to pursue civil litigation, then civil recovery would defeat this policy if it was to be a substitute for criminal confiscation.

\section{IMPLICATIONS IN TERMS OF HUMAN RIGHTS}

Civil recovery proceedings are both civil in domestic and European Convention law. In $A R A v H e$ \& Chen [2005] EWHC 3021 (Admin) the point was taken that civil recovery proceedings represent an unjustified breach of property rights contrary to Article 1 of Protocol 1 of the ECHR. The submission was rejected.

However, this should not be taken to imply that there are no ECHR implications. Article 1 (protection of property) and Article 8 (right to respect for private and family life) may well be engaged. Furthermore, the investigator in each case on whom the powers are conferred must fall within a description specified in an order made for these purposes by the Secretary of State under section 453 of POCA. The powers in question fall within Article 8.2 by virtue of being necessary for the prevention of crime, and accredited financial investigators have functions in the prevention of crime. 
Civil process to confiscate property obtained through unlawful conduct is too good to waste. It hurts criminals in the most effective way. The importance of civil recovery should not be underestimated.

\section{RETROSPECTIVE EFFECT}

The powers given to prosecuting authorities as of April 1, 2008 can be used retrospectively. This is clear from section 316(3) of POCA. This sub-section with this interpretation is referred to in the judgment of Waller LJ in ARA $v$ Szepietowski \& Others [2007] EWCA 766. The redistribution of civil recovery powers is irrelevant to this issue; it simply alters the identity of the claimant not the scope of the action. It should, however, be noted that the new cause of action was made retrospective but subject to a limitation period of 12 years. Time runs from the date the cause of action accrues (see ss 27A92 and A94 of The Limitation Act 1980).

\section{LESSONS TO BE LEARNED FROM BALFOUR BEATTY CASE}

\section{Background}

In civil recovery, property obtained by unlawful conduct can be recovered. The provisions do not require a specific offence to be established against any individual or company. Balfour Beatty voluntarily brought to the attention of the SFO certain unlawful conduct.

The unlawful conduct related to irregular payments and inaccurate accounting which failed to comply with the requirements of section 221 of the Companies Act 1985. These irregularities were in connection with the Bibliotheca project in Alexandrina, Egypt. Once the matter was reported to the SFO by Balfour Beatty, the SFO conducted an investigation.

A consent order was agreed before the High Court on October 6, 2008. Balfour Beatty agreed a settlement of $£ 2.25$ million, together with a contribution to costs of the civil recovery order proceedings.

In simple cases where an agreed sum is to be received by the authority which conducted civil recovery proceedings, the Director of that authority is required to appoint a trustee to receive the agreed sum and deal with it (ie transfer it to the Home Office). In complex cases it may be necessary to appoint a receiver. A substantial part of that sum returns to the prosecuting authority under the incentive scheme. The trustee is nominated under section 266(2) of POCA and must be indemnified by the Director against any claim or action brought against the trustee.

This was the very first civil recovery under the new powers made available since April 2008 to the Serious Fraud Office and other prosecuting authorities - powers which were available only to the now abolished Asset Recovery Agency.

\section{Main lessons}

The main lessons to be learned from this case are:

(a) Encourage corporates and individuals to self-report wrong doing so that the prosecuting authority may consider whether civil recovery is appropriate as opposed to criminal prosecution; the latter always remains an option.

(b) If civil recovery is appropriate then long and prolonged criminal investigations can be avoided with obvious implications with regard to costs and resources. This case showed the importance of these new powers and how they can be used effectively. There were also some lessons to be learned with regard to overseas corruption (the SFO's policy in regard to overseas corruption is set out in the booklet SFO Policy in dealing with overseas corruption).

(c) If there are parallel civil recovery and criminal investigations then the costs of the criminal investigation cannot be claimed from any civil recovery settlement but there is nothing to stop prosecuting authorities from negotiating costs.

(d) If there are victims to be compensated (and there were none in the Balfour Beatty case) then criminal confiscation may be the best option as a compensation order can be made through a confiscation order on conviction.

(e) In civil recovery proceedings the victim has to ask for a declaration from the High Court for compensation from unlawfully recovered property. However, there is nothing in the legislation to stop the prosecuting authority, if satisfied, to do this on the victim's behalf and include it in any settlement or successful civil recovery proceedings.

The second case of civil recovery conducted, once again by the SFO, is that of AMEC PlC (an international engineering and project management firm). It was AMEC that brought the matter to the attention of the SFO in March 2008 following an internal investigation into receipt of unlawful payments.

There was an investigation and it was determined that the payments/receipts were contrary to section 221 of the Companies Act 1985. AMEC paid nearly $£ 5$ million under an agreed consent order and also costs of the civil recovery proceedings.

The lesson to be learned from both the Balfour Beatty and AMEC cases, in particular, is that corporates are bringing irregular conduct to the attention of the appropriate authorities and improving their internal practices to stamp out unlawful conduct rather then face criminal proceedings. It is interesting to note that unless an undertaking is given that there will be no criminal proceedings upon civil settlement, criminal proceedings remain an option in law, but if such proceedings are commenced then there is scope for an abuse argument. 
Furthermore, it might defeat the policy of self-reporting unlawful conduct and in practical terms may be self defeating.

\section{INTERNATIONAL MATTERS}

The Proceeds of Crime Act 2002 (External Requests and Orders) Order 2005 has been made under section 444 of POCA and came into effect on January 1, 2006. Now any country can make a request to the UK jurisdiction for a restraint order or registration of a confiscation order made in the requesting state. The designated countries requirement has been abolished. As a consequence of this the SFO has been able to give assistance to countries such as the Islamic Republic of Iran in restraint proceedings (see judgment of Gross J in Al-Zayat [2008] EWHC 315 (Crim))

\section{Principal definitions}

An external request is a request to restrain relevant property identified in the request (s 447(1)). An external order is one which is made by an overseas court against property obtained as a result, or in connection with, of unlawful conduct, and is for the recovery of specified property or money (s 447(2)). Unlawful conduct is "criminal conduct" as defined by English law (s 447(3)).

\section{Action required on receipt of request}

When a request is received the Secretary of State will refer it to the appropriate prosecuting authority. The restrain order may be made under Article 8 of the external order if the conditions in Article 7 are satisfied, ie either an investigation has begun or criminal proceedings have commenced in the requesting state; there is reasonable cause to believe that the offender named in the request has benefited from unlawful conduct; relevant property in England \& Wales has been identified and such property is required to satisfy any confiscation order that may be made in the requesting state; that there is a risk of dissipation without a restraint order.

Provided these conditions are satisfied the court will not determine the merits of the proceedings in the overseas jurisdiction: see Government of India v Quattrocchi [2004] EWCA Civ 40. It should be noted here that only property located within the domestic jurisdiction can be restrained. A world wide restrain order cannot be made (unlike a domestic restrain order): King v Serious Fraud Office [2008] EWCA Crim 530.

The order may make exceptions for living expenses and legal fees from restrained assets provided no other assets elsewhere are available. The order may also require disclosure of any further assets believed to be within the jurisdiction, and may only be made on the application of the relevant Director of the prosecuting authority. It cannot be applied for directly by the requesting state: Article 9(1)(b).
There is a duty of full and frank disclosure. Any material facts not disclosed may result in the discharge of the order. The procedure is to prepare a witness statement in support of the application for the restraint order and the letter of request from the requesting state may be disclosed. Once the order is obtained, it must be served on all affected parties but the witness statement may only be served on the defendant(s) named within the order.

Innocent third parties having an interest (legal or beneficial) in property restrained may also be prevented from dealing with restrained property. There can be, and frequently are, provisions for substitutes' service of the order if parties are outside the jurisdiction.

\section{Registration of an external order}

This is governed by Article 20(1). The external order may be registered if the conditions in Article 21 are satisfied (see Article for details). It should, however, be highlighted that one specific requirement is that the external order complies with the Human Rights Act 1998. So, for example, if a confiscation order is made in a foreign jurisdiction and a request to register it to confiscate property located in the English jurisdiction is received it cannot be registered if it can be shown that the confiscation order did not comply with ECHR requirements.

This is in contrast to the making of restraint orders as the latter orders only preserve property for the satisfaction of a confiscation order. A restraint order does not transfer property rights or deprive the owner of it. A confiscation order deprives the defendant of the property: see Barnette v Government of the United States of America [2004] UKHL 37 for the application of Article 6 of ECHR to the registration of external confiscation orders.

To satisfy the external order a receiver may be appointed, and time to pay may be allowed - see Article 26(2) of the 2005 order.

The assistance that can be provided amounts to:

(a) protecting property from dissipation by obtaining a restraint order;

(b) managing property by appointing a management receiver;

(c) enforcing an external confiscation order.

\section{$U K$ requests to foreign jurisdictions}

These are made pursuant to section 74 of POCA if the conditions in section 40 have been satisfied. The UK can make requests to apply for restraint orders obtained in the domestic court for registration overseas if property is located in the overseas jurisdiction and for registration of a domestic confiscation order. The request is forwarded through the Secretary of State (UK Central Authority at the Home Office) by a letter of request setting out details of the request and any court order made. It will be governed by the legal requirements of the overseas 
jurisdiction and it is essential to consult the requirements set out in the relevant treaty between the UK and the country to which the request is directed. Most countries offer mutual legal assistance, but some are more difficult then others.

\section{Repatriation of confiscated assets}

It is interesting to note that assets confiscated in this jurisdiction are not usually repatriated to the requesting state unless there are special reasons for doing so, and then it is decided on a case by case basis. However, there is a memorandum of understanding between the UK on the one hand and the USA and Canada on the other that 50 per cent of net proceeds will be returned. A similar memorandum of agreement came into effect on December 7, 2009 between the UK and the Cayman Islands. Also, parties which have agreed to the United Nations AntiCorruption Convention return net proceeds confiscated of state funds.

Assets confiscated in a foreign jurisdiction at the request of the UK may or may not be returned to this country depending on the legislation of the foreign state but the confiscation order is reduced in the amount of the confiscated assets even if these are not returned to the UK

\section{CONCLUSION}

Civil recovery is an important tool in the armory of prosecutors to deprive those who have obtained property through unlawful conduct. Its importance must not be under- estimated. Mutual legal assistance is also very important as without it assets can be transferred overseas, and the person who obtained these ill-gotten gains cannot be deprived of those assets.

The whole purpose of civil recovery and criminal confiscation is to deprive offenders of their ill-gotten gains; its purpose is not to enrich the state. Asset recovery is important because it deters offenders from committing financial crime, disrupts the criminal economy and does not allow offenders to enjoy the benefit of their crimes.

- The views expressed herein are those of the author. They are not representative of the Serious Fraud Office, any other government department or organization. Independent legal advice should always be taken in relation to these and other matters.

\section{Philip F J Mobedji}

Barrister; Senior Restraint and Confiscation Lawyer, Serious Fraud Office. 